\title{
Sodium Arsenite Inhibits Proteoglycan Synthesis by Vascular Endothelial Cells in Culture
}

\author{
Yasuyuki Fujiwara, Yusuke Nakase, and Toshiyuki Kaji* \\ Department of Environmental Health, Faculty of Pharmaceutical Sciences, Hokuriku University, Ho-3 Kanagawa-machi, Kanazawa \\ 920-1181, Japan
}

(Received February 28, 2005; Accepted March 28, 2005; Published online April 5, 2005)

\begin{abstract}
Several epidemiological and experimental studies have demonstrated that exposure to arsenic is associated with vascular disease such as atherosclerosis. Since vessel proteoglycans (PGs) are key molecules in the progression of the vascular lesion, we investigated the effect of arsenic on the synthesis of PGs in cultured bovine aortic endothelial cells. The results indicate that sodium arsenite $\left(\mathrm{NaAsO}_{2}\right)$ significantly decreases the accumulation of both heparan sulfate PGs and chondroitin/dermatan sulfate PGs in the cell layer and the conditioned medium of the cells without nonspecific cell damage and inhibition of whole protein synthesis. While sodium arsenate $\left(\mathrm{Na}_{2} \mathrm{HAsO}_{4}\right)$ did not influence PG synthesis, arsenic trioxide $\left(\mathrm{As}_{2} \mathrm{O}_{3}\right)$ inhibited PG synthesis as a result of nonspecific cell damage. The present data suggest that arsenite may contribute to the progression of atherosclerosis through inhibition of PG synthesis in vascular endothelial cells.
\end{abstract}

Key words — arsenite, glycosaminoglycan, proteoglycan, vascular endothelial cell, atherosclerosis

\section{INTRODUCTION}

Proteoglycans (PGs) are a heterogeneous group of molecules that are prominent constituents of both the extracellular matrix and the cell surface and have the common structure of a core protein, to which one or more glycosaminoglycan (GAG) chains are covalently attached. ${ }^{1)}$ Vascular endothelial cells predominantly synthesize and secrete the large heparan sulfate PG (HSPG), perlecan, ${ }^{2)}$ and the small chondroitin/dermatan sulfate PG (CS/DSPG), biglycan. ${ }^{3)}$ Vascular PGs are involved in the pathogenesis of vascular diseases as well as in the regulation of arterial properties such as vascular permeability, lipid metabolism, hemostasis, thrombosis, and extracellular matrix assembly. ${ }^{47)}$ In addition, PGs influence the regulation of vascular endothelial and smooth muscle cell functions by modulating growth factor availability and function. ${ }^{8-10)}$

Atherosclerosis is a vascular lesion which is initiated by functional damage in vascular endothelial cells followed by vascular smooth muscle cell hy-

\footnotetext{
*To whom correspondence should be addressed: Department of Environmental Health, Faculty of Pharmaceutical Sciences, Hokuriku University, Ho-3 Kanagawa-machi, Kanazawa 9201181, Japan. Tel. \& Fax: +81-76-229-6208; E-mail: t-kaji@ hokuriku-u.ac.jp
}

perplasia in the intima of the vascular wall. ${ }^{11)} \mathrm{We}$ have previously shown that the environmental pollutants lead and cadmium, which have been shown to induce atherosclerosis, ${ }^{12,13)}$ exhibit specific toxicity in vascular endothelial and smooth muscle cell functions such as the proliferation, fibrinolysis, and extracellular matrix formation. ${ }^{14)}$ In addition, we found that the lead-induced inhibitory effect on endothelial cell proliferation is due to a lower response of the cells to endogenous fibroblast growth factor2 (FGF-2) caused by suppression of perlecan synthesis in the cells. ${ }^{15)}$ Cadmium also perturbs the synthesis of PGs in vascular endothelial ${ }^{16,17)}$ and smooth muscle cells. ${ }^{18)}$ Based on these findings, we have proposed that the mechanisms underlying vascular toxicity of heavy metals involve abnormal PG metabolism in vascular cells. ${ }^{19)}$

Epidemiological studies have shown that arsenic as well as cadmium and lead is a possible risk factor for vascular disease related to atherosclerosis. In the United States, it has been reported that there is a correlation between standard mortality ratios for cardiovascular disease and arsenic levels in drinking water. ${ }^{20,21)}$ In addition, exposure to arsenic in artesian well water is associated with "Blackfoot disease" ${ }^{22)}$ and with increased mortality from cardiovascular cerebrovascular disease. ${ }^{23-26)}$ The inorganic pentavalent form of arsenic (arsenate) is the predomi- 
nant type of arsenic found in drinking water. Arsenate is reduced to the trivalent form (arsenite) in vivo, which can be further metabolized to mono- and dimethylated derivatives. ${ }^{27)}$ Among inorganic arsenics, arsenite is in general the most toxic form. ${ }^{28)}$ It is likely that the cellular mechanisms and regulatory pathways for vascular disease in response to arsenite may involve dysfunction of vascular cells, including inflammatory, coagulating activity and impairs nitric oxide homeostasis. ${ }^{29)}$

Arsenite accelerates atherosclerosis in apolipoprotein E-deficient mice, a model of human atherosclerosis. ${ }^{30,31)} \mathrm{We}$ hypothesized that arsenite perturbs the regulation of PG synthesis in vascular cells during the progression of atherosclerosis. In the present study, we investigated the synthesis of PGs in cultured bovine aortic endothelial cells after exposure to sodium arsenite. It was found that sodium arsenite suppresses the synthesis of both HSPGs and CS/DSPGs in the cells.

\section{MATERIALS AND METHODS}

Materials — Vascular endothelial cells derived from bovine aorta were purchased from Dainippon Pharmaceutical (Osaka, Japan). Dulbecco's modified Eagle's medium (DMEM) and ASF 301 medium were obtained from Nissui Pharmaceutical (Tokyo, Japan) and Ajinomoto (Tokyo, Japan), respectively. Tissue culture dishes and plates were from Iwaki (Chiba, Japan). [ ${ }^{35} \mathrm{~S} \mathrm{Na}_{2} \mathrm{SO}_{4}$ (carrier-free) and fetal bovine serum were from MP Biomedicals (Irvine, CA, U.S.A.). $\left[4,5-{ }^{3} \mathrm{H}\right]$ Leucine $(4.44 \mathrm{TBq} /$ mmol) was purchased from Moravek Biomedicals (Brea, CA, U.S.A.). PD-10 columns (disposable Sephadex G-25M) were from Amersham-Pharmacia Biotech (Little Chalfont, U.K.). Sodium arsenite $\left(\mathrm{NaAsO}_{2}\right)$, arsenic trioxide $\left(\mathrm{As}_{2} \mathrm{O}_{3}\right)$, sodium arsenate $\left(\mathrm{Na}_{2} \mathrm{HAsO}_{4}\right)$, DEAE-Sephacel, benzamidine, Tris base and phenylmetanesulfonyl fluoride were purchased from Sigma-Aldrich (St. Louis, MO, U.S.A.). The lactate dehydrogenase (LDH) kit and urea were from Wako Pure Chemical Industries (Osaka, Japan). Cetylpyridinium chloride (CPC) and other reagents were obtained from Nacalai Tesque (Kyoto, Japan). Morphological Examination — Vascular endothelial cells were cultured in DMEM supplemented with $10 \%$ fetal bovine serum in $100 \mathrm{~mm}$ dishes at $37^{\circ} \mathrm{C}$ in a humid atmosphere of $5 \% \mathrm{CO}_{2}$ in air until confluence. They were then transferred into 24-well culture plates and cultured until confluence in
DMEM supplemented with $10 \%$ fetal bovine serum. The medium was discarded and the cell layer was washed twice with serum-free ASF 301 medium. The cell layer was then incubated at $37^{\circ} \mathrm{C}$ for $48 \mathrm{hr}$ in fresh serum-free ASF 301 medium with sodium arsenite $(0.1,0.2,0.5,1$ or $2 \mu \mathrm{M})$. After incubation, the medium was discarded and the cell layer was washed with $\mathrm{Ca}^{2+}, \mathrm{Mg}^{2+}$-free phosphate-buffered saline (CMF-PBS), fixed with methanol, and stained with Giemsa.

Dissociative PG Extraction - Confluent cultures of vascular endothelial cells (passages 11-18) were incubated at $37^{\circ} \mathrm{C}$ for 8,24 or $48 \mathrm{hr}$ in serum-free ASF 301 medium with sodium arsenite $(0.1,0.2,0.5$, 1 or $2 \mu \mathrm{M})$, arsenic trioxide $(2 \mu \mathrm{M})$ or sodium arsenate $(2 \mu \mathrm{M})$ in the presence of $\left[{ }^{35} \mathrm{~S}\right]$ sulfate $(1 \mathrm{MBq} /$ $\mathrm{ml})$. After incubation, the conditioned medium was harvested and solid urea was added to a concentration of $8 \mathrm{M}$. The cell layer was washed twice with ice-cold CMF-PBS and extracted with $8 \mathrm{M}$ urea solution ( $\mathrm{pH} 7.5$ ) containing $0.1 \mathrm{M}$ 6-aminohexanoic acid, $5 \mathrm{mM}$ benzamidine, $10 \mathrm{mM} N$-ethylmaleimide, 2 mM EDTA, $0.1 \mathrm{M}$ phenylmethanesulfonyl fluoride, $0.1 \mathrm{M} \mathrm{NaCl}, 50 \mathrm{mM}$ Tris base and $2 \%$ Triton $\mathrm{X}-100$ at $4^{\circ} \mathrm{C}$ for $15 \mathrm{~min}$. The layer was then harvested by scraping with a rubber policeman. The medium and cell extracts were chromatographed on PD-10 columns equilibrated with $8 \mathrm{M}$ urea buffer (pH 7.5) containing 2 mM EDTA, $0.1 \mathrm{M} \mathrm{NaCl}, 0.5 \%$ Triton X-100 and $50 \mathrm{mM}$ Tris base to obtain high molecular mass (> $3 \mathrm{kDa}$ ) macromolecules.

Incorporation of $\left[{ }^{35} \mathrm{~S}\right]$ Sulfate into GAGs - The incorporation of $\left[{ }^{35} \mathrm{~S}\right]$ sulfate into GAGs was determined by the CPC precipitation method. ${ }^{32}$ Briefly, aliquots of the medium and cell extracts were spotted on filter papers and washed five times for $1 \mathrm{hr}$ in $1 \% \mathrm{CPC}$ with $0.05 \mathrm{M} \mathrm{NaCl}$. The radioactivity of precipitated proteoglycans on the dried filter paper was measured by liquid scintillation counting.

Characterization of PGs — To separate PGs on the basis of differences in charge density, the macromolecules were applied to DEAE-Sephacel $(5 \mathrm{ml}$ of resin) in $8 \mathrm{M}$ urea buffer ( $\mathrm{pH}$ 7.5) containing $2 \mathrm{mM}$ EDTA, $0.25 \mathrm{M} \mathrm{NaCl}, 0.5 \%$ Triton X-100 and $50 \mathrm{mM}$ Tris base. Unbound radioactivity was removed from the column by washing with $30 \mathrm{ml}$ of the buffer. Bound radioactivity was eluted from the column with a linear gradient of $0.25-0.7 \mathrm{M} \mathrm{NaCl}$ in the urea buffer (total volume of $50 \mathrm{ml}$ ).

Nonspecific Cell Damage — Confluent cultures of vascular endothelial cells were prepared in 24well plates. The cells were incubated at $37^{\circ} \mathrm{C}$ for 
$48 \mathrm{hr}$ in $0.25 \mathrm{ml}$ of fresh serum-free ASF $301 \mathrm{me}-$ dium with sodium arsenite $(0.1,0.2,0.5,1$ or $2 \mu \mathrm{M})$, arsenic trioxide $(2 \mu \mathrm{M})$ or sodium arsenate $(2 \mu \mathrm{M})$. After incubation, the conditioned medium was harvested and an aliquot of the medium was used for the assay of LDH activity, an indicator of cell death. Protein Synthesis - Confluent cultures of vascular endothelial cells in 6-well culture plates were incubated at $37^{\circ} \mathrm{C}$ for $48 \mathrm{hr}$ in the presence of sodium arsenite $(0.1,0.2,0.5,1$ or $2 \mu \mathrm{M})$ in $1 \mathrm{ml}$ of serum-free ASF 301 medium and labeled with $\left[{ }^{3} \mathrm{H}\right]$ leucine $(50 \mathrm{kBq} / \mathrm{ml})$ during the last $3 \mathrm{hr}$ of incubation. After incubation, the medium was discarded and the cells were washed twice with icecold CMF-PBS; the cells were scraped off with a rubber policeman in the presence of $0.75 \mathrm{ml} \mathrm{CMF}$ PBS. The culture well was washed with $0.75 \mathrm{ml}$ CMF-PBS and the wash was combined with the cell suspension. The cell homogenate was prepared by sonication and the incorporation of $\left[{ }^{3} \mathrm{H}\right] l$ leucine into the $5 \%$ trichloroacetic acid-insoluble fraction of the cell homogenate was determined by liquid scintillation counting. A portion of the cell homogenate was used for the determination of DNA content by a fluorometric method ${ }^{33)}$ to express the incorporated radioactivity as dpm/ $\mu \mathrm{g}$ DNA.

Statistical Analysis — Data were analyzed for statistical significance by analysis of variance (ANOVA) and Bonferroni's multiple $t$-test. $p$-Values of less than 0.05 were considered to indicate statistically significant differences.

\section{RESULTS}

Figure 1 shows the morphological appearance of cultured vascular endothelial cells after exposure to sodium arsenite at $2 \mu \mathrm{M}$ or less for $48 \mathrm{hr}$. Neither a decrease in cell number nor degenerative change was observed in the cells even after treatment with sodium arsenite, suggesting that sodium arsenite does not exhibit cytotoxicity to vascular endothelial cells.

Figure 2 shows the accumulation of $\left[{ }^{35} \mathrm{~S}\right]$ sulfatePGs in the cell layer and the conditioned medium of vascular endothelial cells after exposure to sodium arsenite. After a 48-hr incubation, sodium arsenite at $0.5 \mu \mathrm{M}$ and more significantly decreased the PG accumulation in both the cell layer and the conditioned medium. The decrease in the PG accumulation by sodium arsenite at $2 \mu \mathrm{M}$ occurred after $24 \mathrm{hr}$ and longer in the cell layer and after $48 \mathrm{hr}$ in the

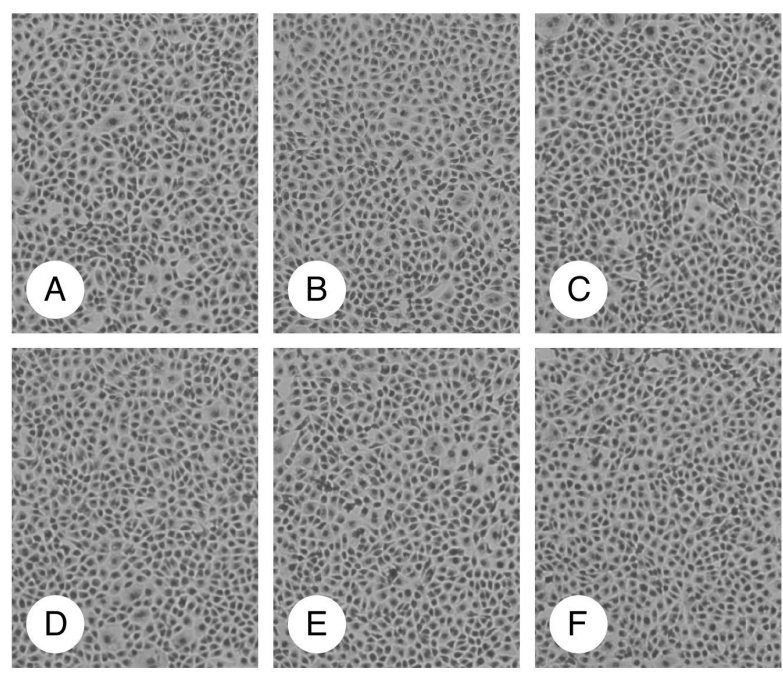

Fig. 1. Morphological Appearance of Vascular Endothelial Cells after Exposure to Sodium Arsenite (Original Magnification $\times 40$ )

Confluent cultures of bovine aortic endothelial cells were incubated at $37^{\circ} \mathrm{C}$ for $48 \mathrm{hr}$ in the presence of sodium arsenite. A, Control; B, sodium arsenite $(0.1 \mu \mathrm{M})$ treatment; C, sodium arsenite $(0.2 \mu \mathrm{M})$ treatment; D, sodium arsenite $(0.5 \mu \mathrm{M})$ treatment; E, sodium arsenite $(1 \mu \mathrm{M})$ treatment; F, sodium arsenite $(2 \mu \mathrm{M})$ treatment.

conditioned medium. These results suggest that sodium arsenite inhibits the synthesis of PGs in vascular endothelial cells, although the inhibitory effect is not marked.

The $\left[{ }^{35} S\right]$ sulfate-labeled PGs were submitted to a DEAE-Sephacel column to separate the PGs into HSPGs and CS/DSPGs based on charge density differences (Fig. 3). In the cell layer, either with or without sodium arsenite treatment, the incorporated $\left[{ }^{35} \mathrm{~S}\right]$ sulfate radioactivity eluted from the column by the $\mathrm{NaCl}$ gradient in two peaks, at approximately 0.4 and $0.5 \mathrm{M}$; these two peaks have been previously confirmed to contain HSPGs and CS/DSPGs, ${ }^{34,35)}$ respectively. It was revealed that sodium arsenite significantly decreased the radioactivity of both HSPGs and CS/DSPGs (80 and 54\%, respectively, of the control). In the conditioned medium, PGs were also eluted by $\mathrm{NaCl}$ at approximately 0.4 and $0.5 \mathrm{M}$; sodium arsenite decreased the radioactivities of HSPGs and CS/DSPGs (85 and 92\%, respectively, of the control). These results indicate that sodium arsenite inhibits the synthesis of both HSPGs and CS/DSPGs in vascular endothelial cells.

Table 1 shows the incorporation of $\left[{ }^{3} \mathrm{H}\right]$ leucine into the acid-insoluble fraction and the leakage of lactate dehydrogenase in vascular endothelial cells treated with sodium arsenite at $2 \mu \mathrm{M}$ or less for $48 \mathrm{hr}$. It was shown that sodium arsenite did not change 

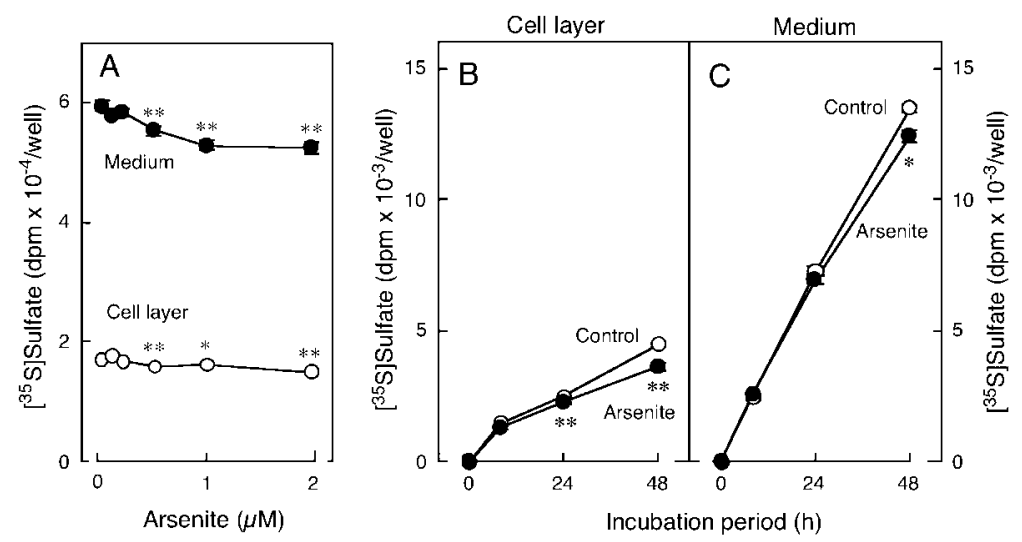

Fig. 2. Incorporation of $\left[{ }^{35} \mathrm{~S}\right]$ Sulfate (A) and Time Course of the Incorporation (B and C) into GAGs Accumulated in the Cell Layer and the Conditioned Medium of Vascular Endothelial Cells after Exposure to Sodium Arsenite

Confluent cultures of bovine aortic endothelial cells were incubated at $37^{\circ} \mathrm{C}$ for $48 \mathrm{hr}$ with sodium arsenite $(0.1,0.2,0.5,1$ or $2 \mu \mathrm{M})$ (A) or incubated at $37^{\circ} \mathrm{C}$ for 8,24 or $48 \mathrm{hr}$ with sodium arsenite $(2 \mu \mathrm{M})(\mathrm{B}$ and $\mathrm{C})$ in the presence of $\left[{ }^{35} \mathrm{~S}\right]$ sulfate. Values are means \pm S.E. of four samples. Significantly different from the corresponding control, ${ }^{*} p<0.05 ; * * p<0.01$.

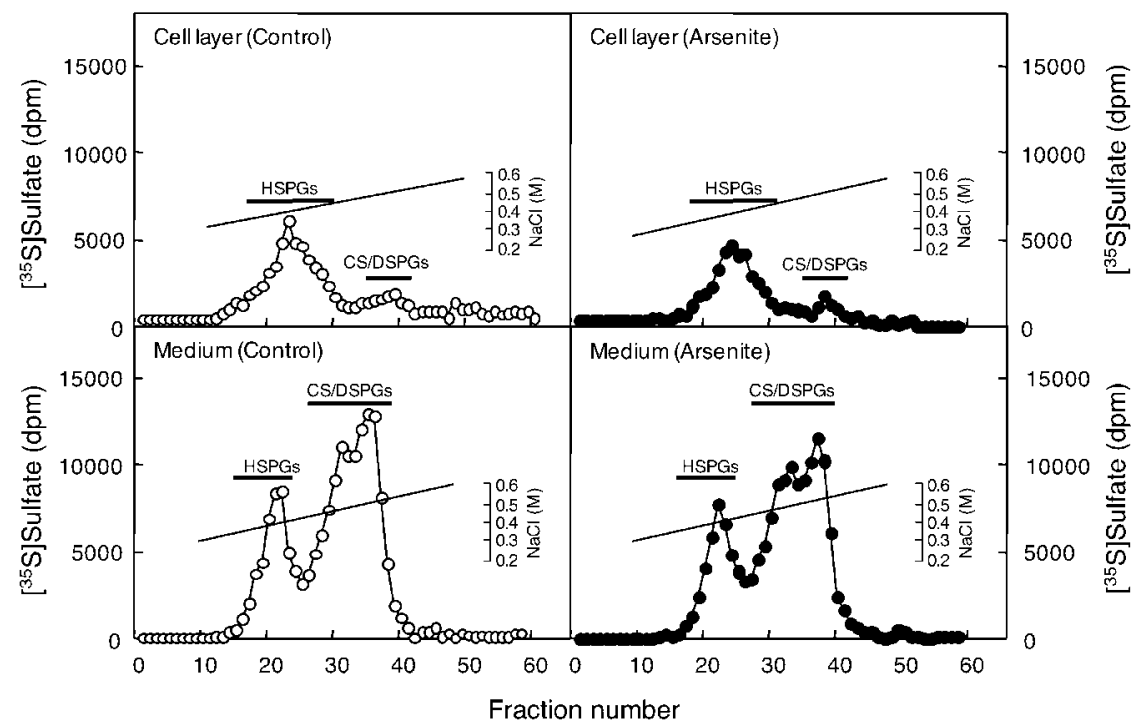

Fig. 3. DEAE-Sephacel Ion Exchange Chromatography of $\left[{ }^{35} \mathrm{~S}\right]$ Sulfate-Labeled PGs Extracted from the Cell Layer and the Conditioned Medium of Vascular Endothelial Cells after Exposure to Sodium Arsenite with a Linear Gradient of 0.25-0.7 M NaCl in 8 M Urea Buffer

Confluent cultures of bovine aortic endothelial cells were incubated at $37^{\circ} \mathrm{C}$ for $48 \mathrm{hr}$ with sodium arsenite $(2 \mu \mathrm{M})$ in the presence of $\left[{ }^{35} \mathrm{~S}\right]$ sulfate.

the $\left[{ }^{3} \mathrm{H}\right]$ leucine incorporation and increased the LDH leakage, suggesting that sodium arsenite-induced inhibition of endothelial PG synthesis was due to neither inhibition of whole protein synthesis nor nonspecific cell damage.

The effects of sodium arsenite, arsenic trioxide, another trivalent arsenic compound, and sodium arsenate on endothelial PG synthesis were compared (Table 2). After a 48-hr incubation, arsenic trioxide as well as sodium arsenite, significantly decreased the accumulation of $\left[{ }^{35} \mathrm{~S}\right]$ sulfate-labeled PGs in both the cell layer and the conditioned medium, suggesting that arsenic trioxide also inhibits PG synthesis in vascular endothelial cells. However, arsenic trioxide significantly increased the activity of LDH that had leaked into the conditioned medium from the cells, indicating that arsenic trioxide-induced inhibition of endothelial PG synthesis results from nonspecific cell damage. On the other hand, sodium arsenate did not influence either PG synthesis or the LDH leakage. 
Table 1. Leakage of LDH into the Medium from Cultured Vascular Endothelial Cells and the Incorporation of $\left[{ }^{3} \mathrm{H}\right]$ Leucine into the Acid-Insoluble Fraction of the Cells after Exposure to Sodium Arsenite

\begin{tabular}{lcc}
\hline \hline & $\begin{array}{c}\text { LDH activity } \\
(\mathrm{IU} / \mathrm{l})\end{array}$ & $\begin{array}{c}{\left[{ }^{3} \mathrm{H}\right] \text { Leucine }} \\
\left(\mathrm{dpm} \times 10^{-2} / \mu \mathrm{g} \text { DNA }\right)\end{array}$ \\
\hline Control & $21.2 \pm 1.80$ & $15.7 \pm 0.93$ \\
$0.1 \mu \mathrm{M}$ arsenite & $16.7 \pm 0.27^{*}$ & $14.8 \pm 0.44$ \\
$0.2 \mu \mathrm{M}$ arsenite & $16.9 \pm 0.57^{*}$ & $15.3 \pm 0.62$ \\
$0.5 \mu \mathrm{M}$ arsenite & $16.0 \pm 0.65^{* *}$ & $15.6 \pm 0.54$ \\
$1 \mu \mathrm{M}$ arsenite & $18.4 \pm 0.96$ & $16.6 \pm 0.55$ \\
$2 \mu \mathrm{M}$ arsenite & $22.6 \pm 0.47$ & $15.6 \pm 0.25$ \\
\hline
\end{tabular}

Confluent cultures of bovine aortic endothelial cells were incubated at $37^{\circ} \mathrm{C}$ for $48 \mathrm{hr}$ with sodium arsenite $(0.1,0.2,0.5,1$, and $2 \mu \mathrm{M})$ in the presence or absence of $\left[{ }^{3} \mathrm{H}\right]$ leucine during the last $3 \mathrm{hr}$ of the incubation. Values are means \pm S.E. of four samples. Significantly different from the corresponding control, ${ }^{*} p<0.05 ; * * p<0.01$.

Table 2. Incorporation of $\left[{ }^{35} \mathrm{~S}\right]$ Sulfate into GAGs Accumulated in the Cell Layer and the Conditioned Medium of Cultured Vascular Endothelial Cells and the Leakage of LDH into the Medium from the Cells after Exposure to Sodium Arsenite, Arsenic Trioxide, and Sodium Arsenate

\begin{tabular}{|c|c|c|c|}
\hline & \multicolumn{2}{|c|}{$\left[{ }^{35}\right.$ S]Sulfate $\left(\mathrm{dpm} \times 10^{-3} /\right.$ well $)$} & \multirow{2}{*}{$\begin{array}{l}\text { LDH activity } \\
\text { (IU/l) }\end{array}$} \\
\hline & Cell layer & Medium & \\
\hline Control & $4.63 \pm 0.15$ & $13.6 \pm 0.33$ & $6.61 \pm 0.33$ \\
\hline Sodium arsenite & $4.02 \pm 0.10^{*}$ & $11.8 \pm 0.33 *$ & $7.22 \pm 0.26$ \\
\hline Arsenic trioxide & $3.36 \pm 0.09 * *$ & $12.1 \pm 0.33^{*}$ & $13.94 \pm 0.37 * *$ \\
\hline Sodium arsenate & $4.31 \pm 0.15$ & $12.3 \pm 0.32$ & $6.08 \pm 0.44$ \\
\hline
\end{tabular}

\section{DISCUSSION}

In the present study, it was shown that sodium arsenite significantly inhibits PG synthesis in vascular endothelial cells without nonspecific cell damage. Although the synthesis of both HSPGs and CS/ DSPGs was inhibited, the inhibition was not due to suppression of whole protein synthesis. In contrast, sodium arsenate did not show such an inhibitory effect, and arsenic trioxide decreased PG synthesis with exhibiting cytotoxicity. These results indicate that the effect of arsenic on endothelial PG synthesis is different among the chemical forms.

Sodium arsenite decreased the accumulation of HSPGs in the cell layer and the conditioned medium to a similar degree ( 80 and $85 \%$, respectively, of the control). On the other hand, the accumulation of CS/ DSPGs in the cell layer was $54 \%$, while that in the conditioned medium was $92 \%$ after treatment with sodium arsenite, suggesting that sodium arsenite inhibits not only the synthesis of both HSPGs and CS/DSPGs but also disturbs the association of CS/ DSPGs to the cell layer. As the result, inhibition of the accumulation of PGs in the cell layer may occur earlier than that in the conditioned medium.

There is a strong interrelationship between atherosclerosis and thrombosis. Vascular endothelial cells have anticoagulant and fibrinolytic properties that contribute to the prevention of vascular lesions such as atherosclerosis. Arsenite inhibits tissue-type plasminogen activator synthesis with induction of plasminogen activator inhibitor-1 synthesis in cultured human microvascular endothelial cells, resulting in a lower fibrinolytic activity of the cells. ${ }^{36)}$ The major PGs synthesized by vascular endothelial cells are perlecan and biglycan, ${ }^{2,3,35)}$ which exhibit antithrombin activity through activation of antithrombin and heparin cofactor II, respectively. ${ }^{37,38)}$ Thus, arsenite may contribute to thrombosis in atherosclerosis by the reduction of endothelial PG synthesis 
as well as the reduction of endothelial fibrinolytic activity.

When vascular endothelium is injured, FGF-2 leaks from the damaged endothelial cells and the growth factor then promotes repair of the damaged endothelium via stimulation of proliferation and migration of the cells near the damaged site in an autocrine fashion. ${ }^{39)}$ Perlecan markedly promotes the binding of FGF-2 to its cell surface receptor. ${ }^{8)} \mathrm{We}$ have previously demonstrated that lead inhibits the repair of wounded endothelial cell layers, which result from a lower response to endogenous FGF-2 caused by inhibition of perlecan synthesis in the cells. ${ }^{15,19)}$ It is likely that arsenite may inhibit the repair process of endothelium as does lead, although it does not injure the endothelial monolayers. In fact, arsenite stimulates the growth of cultured vascular endothelial cells after confluence ${ }^{40,41)}$ but inhibits the $\log$-phase growth of the cells. ${ }^{42}$ )

It was reported that vascular disease, such as Blackfoot's disease, occurred around well waters containing between 4.8 and $15.6 \mu \mathrm{M}$ arsenite in areas of Taiwan. ${ }^{43}$ The human blood concentration of arsenite is three to nine times lower than the environmentally relevant level of arsenite in drinking water. ${ }^{44)}$ These results suggest that the blood concentration of arsenite can be between approximately 0.5 and $5 \mu \mathrm{M}$. In addition, epidemiologically, chronic exposure to arsenite at concentrations exceeding $0.25 \mu \mathrm{M}$ in drinking water is associated with increased mortality from cardiovascular disease. ${ }^{45)}$ In the present study, it was shown that sodium arsenite at concentrations of $0.5 \mu \mathrm{M}$ and more inhibited the synthesis of PGs in vascular endothelial cells. Therefore, it is suggested that inhibition of endothelial PG synthesis by arsenite can contribute to vascular diseases such as atherosclerosis in human beings.

In conclusion, the present data demonstrate the inhibitory effect of sodium arsenite on the synthesis of HSPGs and CS/DSPGs in vascular endothelial cells. The inhibition of endothelial cell PG synthesis by arsenite may contribute to the progression of atherosclerosis through reduction of the endothelial anticoagulant activity and the ability of the cells to respond to FGF-2 during the repair of damaged endothelium.

Acknowledgements This work was partly supported by the Specific Research Fund of Hokuriku University (to T. K.) and a Grant-in-Aid for Young Scientists (B) from the Ministry of Education Cul- ture, Sports, Science and Technology, Japan (to Y. F.).

\section{REFERENCES}

1) Ruoslahti, E. (1988) Structure and biology of proteoglycans. Аnпи. Rev. Cell Biol., 4, 229-255.

2) Saku, T. and Furthmayr, H. (1989) Characterization of the major heparan sulfate proteoglycan secreted by bovine aortic endothelial cells in culture. Homology to the large molecular weight molecule of basement membranes. J. Biol. Chem., 264, 3514-3523.

3) Järveläinen, H. T., Kinsella, M. G., Wight, T. N. and Sandell, L. J. (1991) Differential expression of small chondroitin/dermatan sulfate proteoglycans, PG-I/ biglycan and PG-II/decorin, by vascular smooth muscle and endothelial cells in culture. J. Biol. Chem., 266, 23274-23281.

4) Wight, T. N. (1989) Cell biology of arterial proteoglycans. Arteriosclerosis, 9, 1-20.

5) Camejo, G. (1982) The interaction of lipids and lipoproteins with the intercellular matrix of arterial tissue: its possible role in atherogenesis. Adv. Lipid Res., 19, 1-53.

6) Saxena, U. and Goldberg, I. J. (1994) Endothelial cells and atherosclerosis: lipoprotein metabolism, matrix interactions, and monocyte recruitment. Curr. Opin. Lipidol., 5, 316-322.

7) Berenson, G. S., Radhakrishnamurthy, B., Srinivasan, S. R., Vijayagopal, P., Dalferes, E. R., Jr. and Sharma, C. (1984) Recent advances in molecular pathology. Carbohydrate-protein macromolecules and arterial wall integrity-a role in atherogenesis. Exp. Mol. Pathol., 41, 267-287.

8) Aviezer, D., Hecht, D., Safran, M., Eisinger, M., David, G. and Yayon, A. (1994) Perlecan, basal lamina proteoglycan, promotes basic fibroblast growth factor-receptor binding, mitogenesis, and angiogenesis. Cell, 79, 1005-1013.

9) Hildebrand, A., Romaris, M., Rasmussen, L. M., Heinegard, D., Twardzik, D. R., Border, W. A. and Ruoslahti, E. (1994) Interaction of the small interstitial proteoglycans biglycan, decorin and fibromodulin with transforming growth factor- $\beta$. Biochem. J., 302, 527-534.

10) Ruoslahti, E. and Yamaguchi, Y. (1991) Proteoglycans as modulators of growth factor activities. Cell, 64, 867-879.

11) Ross, R. (1993) The pathogenesis of atherosclerosis: a perspective for the 1990s. Nature (London), 362, 801-809.

12) Houtman, J. R. (1993) Prolonged low-level cadmium intake and atherosclerosis. Sci. Total Environ., 138, 
31-36.

13) Revis, N. W., Zinsmeister, A. R. and Bull, R. (1981) Atherosclerosis and hypertension induced by lead and cadmium ions: an effect prevented by calcium ion. Proc. Natl. Acad. Sci. U.S.A., 78, 6494-6498.

14) Kaji, T. (2004) Cell biology of heavy metal toxicity in vascular tissue. Yakugaku Zasshi, 124, 113-120.

15) Fujiwara, Y. and Kaji, T. (2000) Inhibition of the repair of injured endothelial cell monolayers by lead and its possible mechanisms. J. Health Sci., 46, 14.

16) Kaji, T., Ohkawara, S., Yamamoto, C., Sakamato, M. and Kozuka, H. (1994) Cadmium-induced alteration of glycosaminoglycans with an enhancement of heparin-like activity in cultured vascular endothelial cells. Toxicology, 94, 161-171.

17) Ohkawara, S., Yamamoto, C., Fujiwara, Y., Sakamoto, M. and Kaji, T. (1997) Cadmium induces the production of high molecular weight heparan sulfate proteoglycan molecules in cultured vascular endothelial cells. Environ. Toxicol. Pharmacol., 3, 187-194.

18) Fujiwara, Y., Tsumura, N., Yamamoto, C. and Kaji, T. (2002) Different effects of cadmium on proteoglycan synthesis of arterial smooth muscle cells: increase in small dermatan sulfate proteoglycans, biglycan and decorin, in the extracellular matrix at low cell density. Toxicology, 170, 89-101.

19) Fujiwara, Y. (2004) Cell biological study on abnormal proteoglycan synthesis in vascular cells exposed to heavy metals. J. Health Sci., 50, 197-204.

20) Engel, R. R. and Smith, A. H. (1994) Arsenic in drinking water and mortality from vascular disease: an ecologic analysis in 30 counties in the United States. Arch. Environ. Health, 49, 418-427.

21) Lewis, D. R., Southwick, J. W., Ouellet-Hellstrom, R., Rench, J. and Calderon, R. L. (1999) Drinking water arsenic in Utah: A cohort mortality study. Environ. Health Perspect., 107, 359-365.

22) Tseng, C. H., Chong, C. K., Chen, C. J., Lin, B. J. and Tai, T. Y. (1995) Abnormal peripheral microcirculation in seemingly normal subjects living in Blackfoot-disease-hyperendemic villages in Taiwan. Int. J. Microcirc., 15, 21-27.

23) Chen, C. J., Wu, M. M., Lee, S. S., Wang, J. D., Cheng, S. H. and Wu, H. Y. (1988) Atherogenicity and carcinogenicity of high-arsenic artesian well water. Multiple risk factors and related malignant neoplasms of Blackfoot disease. Arteriosclerosis, $\mathbf{8}$, 452-460.

24) Chen, C. J., Chiou, H. Y., Chiang, M. H., Lin, L. J. and Tai, T. Y. (1996) Dose-response relationship between ischemic heart disease mortality and longterm arsenic exposure. Arterioscler. Thromb. Vasc.
Biol., 16, 504-510.

25) Tseng, C. H., Chong, C. K., Tseng, C. P., Hsueh, Y. M., Chiou, H. Y., Tseng, C. C. and Chen, C. J. (2003) Long-term arsenic exposure and ischemic heart disease in arseniasis-hyperendemic villages in Taiwan. Toxicol. Lett., 137, 15-21.

26) Wu, M. M., Kuo, T. L., Hwang, Y. H. and Chen, C. J. (1989) Dose-response relation between arsenic concentration in well water and mortality from cancers and vascular diseases. Am. J. Epidemiol., 130, 1123-1132.

27) Abernathy, C. O., Liu, Y. P., Longfellow, D., Aposhian, H. V., Beck, B., Fowler, B., Goyer, R., Menzer, R., Rossman, T., Thompson, C. and Waalkes, M. (1999) Arsenic: health effects, mechanisms of actions, and research issues. Environ. Health Perspect., 107, 593-597.

28) Buchet, J. and Lison, D. (2000) Clues and uncertainties in the risk assessment of arsenic in drinking water. Food Chem. Toxicol., 38, S81-S85.

29) Simeonova, P. P. and Luster, M. I. (2004) Arsenic and atherosclerosis. Toxicol. Appl. Pharmacol., 198, 444-449.

30) Simeonova, P. P., Hulderman, T., Harki, D. and Luster, M. I. (2003) Arsenic exposure accelerates atherogenesis in apolipoprotein $\mathrm{E}^{-/-}$mice. Environ. Health Perspect., 111, 1744-1748.

31) Bunderson, M., Brooks, D. M., Walker, D. L., Rosenfeld, M. E., Coffin, J. D. and Beall, H. D. (2004) Arsenic exposure exacerbates atherosclerotic plaque formation and increases nitrotyrosine and leukotriene biosynthesis. Toxicol. Appl. Pharmacol., 201, 32-39.

32) Wasteson, Å., Uthne, K. and Westermark, B. (1973) A novel assay for the biosynthesis of sulphated polysaccharide and its application to studies on the effects of somatomedin on cultured cells. Biochem. J., 136, 1069-1074.

33) Kissane, J. M. and Robins, E. (1958) The fluorometric measurement of deoxyribonucleic acid in animal tissues with special reference to the central nervous system. J. Biol. Chem., 233, 184-188.

34) Kinsella, M. G. and Wight, T. N. (1986) Modulation of sulfated proteoglycan synthesis by bovine aortic endothelial cells during migration. J. Cell Biol., 102, 679-687.

35) Kaji, T., Yamada, A., Miyajima, S., Yamamoto, C., Fujiwara, Y., Wight, T. N. and Kinsella, M. G. (2000) Cell density-dependent regulation of proteoglycan synthesis by transforming growth factor- $\beta_{1}$ in cultured bovine aortic endothelial cells. J. Biol. Chem., 275, 1463-1470.

36) Jiang, S, J., Lin, T. M., Wu, H. L., Han, H. S. and Shi, G. Y. (2002) Decrease of fibrinolytic activity in 
human endothelial cells by arsenite. Thromb. Res., 105, 55-62.

37) Mertens, G., Cassiman, J. J., Van den Berghe, H., Vermylen, J. and David, G. (1992) Cell surface heparan sulfate proteoglycans from human vascular endothelial cells. Core protein characterization and antithrombin III binding properties. J. Biol. Chem., 267, 20435-20443.

38) Whinna, H. C., Choi, H. U., Rosenberg, L. C. and Church, F. C. (1993) Interaction heparin cofactor II with biglycan and decorin. J. Biol. Chem., 268, 3920-3924.

39) Sato, Y. and Rifkin, D. B. (1988) Autocrine activities of basic fibroblast growth factor: regulation of endothelial cell movement, plasminogen activator synthesis, and DNA synthesis. J. Cell Biol., 107, 1199-1205.

40) Barchowsky, A., Dudek, E. J., Treadwell, M. D. and Wetterhahn, K. E. (1996) Arsenic induces oxidant stress and NF- $\kappa \mathrm{B}$ activation in cultured aortic endothelial cells. Free Radic. Biol. Med., 21, 783-790.

41) Barchowsky, A., Roussel, R. R., Klei, L. R., James, P. E., Ganju, N., Smith, K. R. and Dudek, E. J. (1999) Low levels of arsenic trioxide stimulate prolifera- tive signals in primary vascular cells without activating stress effector pathways. Toxicol. Appl. Pharmacol., 159, 65-75.

42) Roboz, G. J., Dias, S., Lam, G., Lane, W. J., Soignet, S. L., Warrell, R. P., Jr. and Rafii, S. (2000) Arsenic trioxide induces dose- and time-dependent apoptosis of endothelium and may exert an antileukemic effect via inhibition of angiogenesis. Blood, 96, 15251530.

43) Tseng, C. H., Chong, C. K., Chen, C. J. and Tai, T. Y. (1997) Lipid profile and peripheral vascular disease in arseniasis-hyperendemic villages in Taiwan. Angiology, 48, 321-345.

44) Pi, J., Kumagai, Y., Sun, G., Yamauchi, H., Yoshida, T., Iso, H., Endo, A., Yu, L., Yuki, K., Miyauchi, T. and Simojo, N. (2000) Decreased serum concentrations of nitric oxide metabolites among Chinese in an endemic area of chronic arsenic poisoning in inner Mongolia. Free Radic. Biol. Med., 28, 11371142.

45) Engel, R. R., Hopenhayn-Rich, C., Receveur, O. and Smith, A. H., (1994) Vascular effects of chronic arsenic exposure: a review. Epidemiol. Rev., 16, 184208. 